\title{
Research on Performance Appraisal for Student Affairs Management Personnel in Chinese Universities
}

\author{
Based on 3E Theory
}

\author{
Nan Ding \\ School of Humanities and Law \\ Northeastern University \\ Shenyang, China
}

\author{
Wanbing Shi \\ School of Humanities and Law \\ Northeastern University \\ Shenyang, China
}

\begin{abstract}
Education, management and service are the three main functions of student affairs management personnel in universities. It is a new issue how to realize effective student affairs management and development of student affairs management personnel, constantly promote the performance of student affairs management and improve the comprehensive quality of the management personnel. As of the application of "3E" standard system (economy, efficiency and effectiveness) in England at the beginning of $1980 \mathrm{~s}$, it has established a complete comprehensive performance appraisal system. "3E" system represents the diversified development trend of performance appraisal system, by which it makes soft environment appraisal system more transparent and scientific, increases the operability of management efficiency and performance appraisal and plays a great promoting effect on the improvement and development of performance appraisal of university counselors. Hence, promoting the performance appraisal of student supervisors based on " $3 E$ " theory is feasible. In this article, on the basis of connotation of performance appraisal and combining with the basic connotation and practical value of $3 \mathrm{E}$ theory, it analyzes the current situation of performance appraisal of student affairs management personnel in Chinese universities as well as the existing problems and causes. In terms of the problems and causes existing in performance appraisal, it puts forward constructive opinions and suggestions on establishment of performance appraisal system of student affairs management personnel in Chinese universities for the purpose of promoting the development of student affairs management personnel in Chinese universities in a healthy and ordered way.
\end{abstract}

Keywords-3E theory; China; student affairs management personnel in universities; performance appraisal; problem

\section{CONNOTATION OF 3E THEORY}

Put forward by Terry Fenrick in 1995, at the earliest, 3E theory is a dominated appraisal mode of public financial budget performance management in western countries. With the development for recent twenty years, the theory is widely applied in all the social fields, from enterprise audit to evaluation of government performance, from public financial evaluation to soft strength evaluation, etc. This theory abstracts the beneficial practical experience of performance audit, absorbs the theoretical achievements of other subjects and puts forward the organically-combined mode of economy, efficiency and effectiveness; since the three words start with "E", it is called as "3E" theory which has significant practical application values. The so-called $3 \mathrm{E}$ theory is used for appraising the performance of an organization or individual person within certain period based on the appraisal indicator organically integrated with economy, efficiency and effectiveness, and its indicator system mainly composes of economy appraisal, efficiency appraisal and effectiveness appraisal.

"Economy appraisal indicator" mainly refers to that organization or individual person reduces resource consumption as much as possible or fully utilizes the existing resources in input at certain level to obtain maximum input with optimal proportion [2].

"Efficiency appraisal indicator" mainly reflects the proportion relationship of work achievements and resources consumed in work [3]

"Effectiveness appraisal indicator" refers to achievement degree of work or service of organization or individual person to goal or the degree satisfying public demands and expresses the degree of final influence of output on the accomplishment of political objectives, including output quality and effect of public and social expectation, etc.[4] Thus it can be seen that " $3 \mathrm{E}$ " theoretical indicator system correspondingly pays more attention on cost saving, i.e. emphasize economy, which also is the most fundamental value criterion of " $3 \mathrm{E}$ " theoretical indicator system.

\section{FEASIBILITY OF 3E THEORY APPLIED IN PERFORMANCE APPRAISAL SYSTEM OF STUDENT AFFAIRS MANAGEMENT PERSONNEL IN UNIVERSITIES}

$3 \mathrm{E}$ theory opens up a new perspective and approach for research on performance appraisal system of student affairs management personnel in Chinese universities on overall investigating the performance appraisal above-mentioned from a systematic perspective. It emphasizes the harmonious 
development of economy, efficiency and effectiveness, focuses on unity of the three factors and applies them in performance appraisal, which contributes to measurement and appraisal on the performance of student affairs management personnel in universities with a definite system. The performance appraisal system of student affairs management personnel in Chinese universities considers promotion of the performance as ultimate objective, makes efforts to maximum effectiveness with minimum investment (economy), promotes their work efficiency to the greatest extent and changes the thought of appraising for appraisal. From the perspective of $3 \mathrm{E}$ theory, investigate the resources (manpower, materials and finances) input to counselors by the university and the factors output by the student affairs management personnel, which contributes to promoting the work efficiency, level and quality of student affairs management personnel in Chinese universities and providing management and decision basis for counselors.

\section{Problems EXISTING IN PERFORMANCE APPRAISAL System OF STUdENT AFFAIRS MANAGEMENT PERSONNEL IN UNIVERSITIES}

\section{A. Lack of Understanding forPerformance Appraisal System}

On one hand, in performance appraisal on student affairs management personnel, management personnel in charge of student affairs in university will trend to equalitarianism in most cases and consider appraisal as going through the motions, i.e. rate all the appraised much the same, resulting in an easygoing atmosphere; on the other hand, the appraisal organizers consider appraisal as just an assessment on the results of student affairs management personnel, losing sight of the guidance and incentive functions of appraisal, resulting in current appraisal results lacking of feedback and proper use and phenomenon of only appraisal without feedback. Some schools carry out better that it links the appraisal results with the bonus of student affairs management personnel, but the management personnel only know the bonus quantity more or less issued without the causes, so that they are unable to know their shortcomings, not to mention improvement or promotion.

\section{B. Lack of Systematic Theoretic Guidance and Scientific Methodological Demonstration}

At present, performance appraisal on student affairs management personnel in Chinese universities is still in exploratory stage based on experience accumulation, lacking of solid theoretical basis and method. Same to personnel appraisal, generally university carries out performance appraisal on student affairs management personnel at the end of the year or semester. Upon notice of HR department, the student affairs office appraises the work accomplishment condition of student affairs management personnel with fixed table, mainly by means of quantitative assessment combining with four factors of "morality, ability, attitude and performance" and the work characteristics of student affairs management personnel. In addition, the research result of performance appraisal of student affairs management personnel only involves in single appraisal on certain ability of counselor in common case, and the research on comprehensive rating as well as related appraisal standard and method is far from systematic. The immaturity and imperfection of performance appraisal of student affairs management personnel in theory will influence the development of student affairs management team and restrict the development of higher educational business.

\section{Imperfection of Performance Appraisal System, Lacking of Guidance}

The performance appraisal system only takes output performance into consideration without input cost. In existing performance appraisal system of student affairs management personnel, most of which only consider the output performance of student affairs management personnel in aspects of education, management, scientific research and social service, and all the professor, associate professor, lecturer and teaching assistant are measured with unified standard. However, university invests different costs in each student affairs management personnel, so that it is very unscientific to rank them in same platform or require the lecturer has same output performance with professor, which is unable to express the definition of effectiveness in performance.

\section{Pay all Attention on the Performance Appraisal of Student Affairs Management Personnel, But Have No Performance Management.}

Appraisal is born to let the leaders, as well as student affairs management personnel themselves, thoroughly understand the work of the student affairs management personnel. On such basis, the leaders can carry out effective guidance and control, at the same time, the student affairs management personnel can improve their own shortcomings. However, in existing performance appraisal, the understanding of appraiser and student affairs management personnel on appraisal is only limited to marking and almost all the universities have their own internal appraisal modes, preparing forms, completing forms and constantly searching for different mathematical methods to calculate and appraise the performance of student affairs management personnel; however, the appraisal results play no practical function and they are unable to find a way out. While, the ultimate problem is wrong in overall conception, if the appraisal result is unable to promote the whole performance of the university, it will become an additional burden internally. Performance appraisal only focuses on appraisal behavior while performance management emphasizes the process management which enlarges the appraiser's and student affairs management personnel's mind of going through the motions and reduces the effectiveness of appraisal.

\section{Causes Analysis on PRoblems Existing in PERFORMANCE APPRAISAL OF STUDENT AFFAIRS MANAGEMENT PERSONNEL}

\section{A. Ambiguous Work Positioning, in Terms of System Mechanism of Performance Appraisal of Student Affairs Management Personnel}

In existing system of higher education management, the autonomous right of university is insufficient due to excessive concentration power of administrative department for education. On this occasion, in order to express the school running guidance and police of the state, well realize the 
functions of talent cultivation, scientific research, social service and cultural inheritance put forward by the state, the university must define corresponding school running objectives, and the system established for this purpose is designed for the accomplishment of the overall objectives of the university; moreover, as the main body of talent cultivation, the performance appraisal system of student affairs management personnel will be no exception. In practice, university organization, as executor, it is hard to adjust and innovate related system prepared by the state according to its practice. On the other hand, as an entity, university certainly has internal management requirements and put formulation for school's mission and cultivation objectives based on school development for constant development to adapt situation demands and strengthen its own development advantages. Such principle of giving priority to organization objective, expressed in level of appraisal management system, certainly will lowers degree of participation of student affairs management personnel, so that they are hard to realize individual development. The reason why some universities emphasize performance appraisal of student affairs management personnel is mainly to provide basis for managing student affairs management personnel; therefore, in performance appraisal of student affairs management personnel in universities, university pay more attention on the examination of accomplishment situation of periodical organization objectives than the work process and station of student affairs management personnel or their development situation.

\section{B. Lacking of Appraisal Idea with Advancement of Time, in Terms of Management Method of Appraisal}

In the practice of performance appraisal of student affairs management personnel in our country, they lack of initiative and are in passive position; in addition, their rights to know, to participate in, to make decision of and to monitor related policies concerning the establishment of appraisal indicator system, application of appraisal method and use of appraisal results are weakened to different degrees. The appraisers are in dominant position in performance appraisal of student affairs management personnel; however, they lack of ideas considering student affairs management personnel as main body, resulting in the student affairs management personnel do not buy or trust the appraisal results. The student affairs management personnel, as appraisal object, have lower degree of participation in appraisal, not to mention the democratic and equal communication between the appraisers and objects appraised; in the meanwhile, the intensive competition among student affairs management personnel and little communication between appraisers and objects appraised influence the solidarity and cooperation among student affairs management personnel and between the appraisers and objects appraised, which goes against the establishment of harmonious HR management environment in university and formation of democratic and equal environment.

\section{Preferring Accomplishment of Work Objectives for Promotion of Internal Quality at Guiding Level of Appraisal}

At present, at appraisal guiding level, it pays excessive attention on the accomplishment of work objectives, leading to that the design of most indicator systems take quantization as precondition. The performance appraisal of student affairs management personnel is excessively quantized, which is not concerning the quantization indicators, instead, some universities do not well combine the indicators with work objectives. In the selection and preparation of quantization indicators, the student affairs management personnel in universities are required to precisely master the relationship between the work objectives and quantization indicator, so as to guarantee the scientific appraisal guidance. Only well mastering the degree of quantity and standard of quality can it balance the quality and quantity.

Any university is required to put forward certain quantization indicator in performance appraisal of student affairs management personnel, which is the overall task load subject to the school running thought and cultivation objectives as well as is required for promoting the school running level and effectiveness; however, the quantity and quality are not supposed to be in relationship of mutual repulsion. The student affairs management personnel in Chinese universities engage in ideological and political education on college students and routine management work, play the roles of college students' navigator of life development, mentor of study and being successful, counselor of mental health, protector of rights and interests as well as the bearer of scientific research in teaching, integrated all the roles in one, so that it is not difficult to imagine the difficulty and breadth of their work.

The routine management of college student affairs is easy to quantize; hence, with the influence of the existing performance appraisal system of student affairs management personnel, the student affairs management personnel approach the work objectives which can be quantized in an unpractical way, resulting in the main work of student affairs management personnel - ideological and political education work is neglected. As for the consequence of such guidance, the first is that the student affairs management personnel put their main energy on pursuing the routine management work to quantize, ignoring and weakening the input in ideological and political education work, which severely influences the quality of ideological and political education work in Chinese university; the second is that the improvement of their won quality of student affairs management personnel is influenced, they will pay less attention on politics of current events, which may lead to overall slump in terms of their moral cultivation, level of political theory and physical and mental quality. Such deviation on appraisal guidance becomes the ultimate cause of lower overall quality of student affairs management personnel and occurrence of job burnout. 
D. Failing to Be Fully Aware of the Significance of Use of Appraisal Result in Terms of Application of Appraisal Result.

Generally, the appraisal results are often applied in promotion, salary distribution and rewards and punishment. However, most of the appraisal results in current universities ultimately are not linked with the rewards, punishment, promotion and training of counselors, even seriously divorced, so that the appraisal results are unable to play a due role, resulting in the performance appraisal has slight significance. Both appraisal department and student affairs management personnel wrongly consider appraisal as an evaluation on work results, i.e. a summary and generalization of work in the past year, ultimately are not aware of the guidance or incentive function of appraisal result, or consult the problems existing in work of student affairs management personnel, leading to formalism.

\section{E. In the Design of Evaluation Index System, the Crucial Point Is Evaded and the Concept of Cost and Income Is Weak.}

It emphasizes the perfect combination of qualitative assessment and quantitative assessment in a complete performance appraisal system. Lack of quantitative assessment will lead that the result of assessment is too subjective and not scientific enough. Total quantitative examination is too rigid, more than that some aspects of assessment cannot be quantified such as attitudes, political heights and other indicators. As far as the performance appraisal system of college counselors, it is easy to determine the nature but difficult to quantify, which leads that during the design of performance appraisal of student affairs management personnel a number of universities evades the crucial point and put more focus on the nature not quantification. They evaluate the work of student affairs management personnel simply by assessing the subject as "good" or "bad". This results that the entire performance appraisal system of student affairs management personnel lacks the quantitative examination and does not have the corresponding data to support as the result of examination. Ignoring the large amount of extra work assessment in the work of student affairs management personnel cannot motivate the personnel; instead it has attacked the enthusiasm of student affairs management personnel and the student affairs managers, which often falls into the erroneous zones of pursuing perfect perfection in performance appraisal. The erroneous zones include pursuing the standardization and integrity of performance forms, pursuing the advance of performance tools and performance methods, pursuing all the satisfaction of assessment objects to performance appraisal and the standardization of performance appraisal process.

\section{COUNTERMEASURES ON IMPROVING PERFORMANCE APPRAISAl OF STUdENT AFFAIRS MANAGEMENT PERSONNEL IN CHINESE UNIVERSITIES BASED ON 3E THEORY}

\section{A. Government's Policy Suggestions onOptimizing \\ Performance Appraisal System of Student Affairs \\ Management Personnel in Chinese Universities}

It shall take advantages of the functions of government's macro regulation and control, and prepare the basic standards for performance appraisal of college counselors. First, it shall establish the basic standards for performance appraisal of college counselors at the national level. The Ministry of Education should further coordinate with Central Preparation and Organization Department, Ministry of finance, personnel and other departments, and play the government's macrocontrol functions. It shall use the government's authorizes to coordinate, which is for improving the related policies about the performance appraisal of counselor, as well as establishing each mechanism. Meanwhile, we should also step up efforts to supervise the performance appraisal of counselors, and timely master the grass-root work, find problems, and study countermeasures, so as to ensure the effective implementation of policies. Construct the index system platform of performance appraisal system of counselors in state universities; Secondly, establish a scientific economic index system of performance of national counselors with practical significance, which includes such indexes as setting up environment, implementation effect, service quality, education management efficiency and realization of function target. Long term, continuous and effective monitoring research will help the government to strengthen the macro management and strategic control of the professionalization and specialization of college counselors through legal, economic and other means, which is beneficial to meet the demand of university counselors for information consultation and so on, as well as conducive to the communication and research between universities counselors. Finally, it will be beneficial to the realization of ideological and political education goal in colleges and universities, and the development of professionalization and specialization of instructors.

\section{B. Management Measures on Improving the Performance Appraisal System of Student Affairs Management Personnel in Universities}

The team of student affairs management personnel in universities plays a main role in carrying out ideological and political education for college students. For the realization of scientific and effective ideological and political education, in a certain sense, it depends on whether the performance appraisal mechanism of university student affairs management personnel plays the basic role of serving and supporting the selection and employment of student affairs management personnel, depends on whether the performance appraisal system of student affairs management personnel is used to improve their abilities of organization and management, language and expression, communication and coordination, research and competence, as well as its contribution of improving the quality of ideological and political education in colleges and universities. First, we should focus on practical results and establish a performance 
appraisal mechanism which embodies scientific development for student affairs management personnel in universities; Second, set up the organization and leadership mechanism of performance appraisal of student affairs management personnel, and strengthen the scientific, systematic and democratic performance appraisal of student affairs management personnel; Third, establish and improve the high-quality team for performance appraisal of student affairs management personnel. The performance appraisal team is the main body of evaluation, whose quality determines the authenticity, reliability, objectivity and fairness of performance appraisal of student affairs management personnel. In addition defining the responsibilities of student affairs management personnel and making the reasonable performance objectives, it is necessary to have a high-quality team of performance appraisal for improving the reliability, validity and accuracy of performance appraisal of student affairs management personnel. The highquality evaluation body shall master the guiding ideology, theory and skills of performance appraisal, and be familiar with the characteristics of student affairs management work. They should also have noble occupation morality and sense of responsibility to ensure the effective implementation of performance appraisal. Fourth, it shall organize the exams to promote the structure to enhance the feedbacks of communication and application of results of performance appraisal of student affairs management personnel in universities. The results of management personnel's performance appraisal are linked with their job's promotion and adjustment, which will make the excellent management personnel stand out and make the management personnel who has limited ability and is not popular with students feel the stress and crisis. And it is necessary to encourage the student affairs management personnel who has good ability and outstanding performance, and put them in an important position

\section{CONCLUSION}

At present, there are very few researches on performance appraisal of student affairs management personnel in university at home and abroad. But on the premise that the university makes clear the performance appraisal result of student affairs management personnel and its main influence factor, the strategies and methods will be found to improve the performance of student affairs management personnel, which will finally improve the value and performance of student affairs management personnel. Focusing on the theme of constructing the performance appraisal system for student affairs management personnel, this thesis summarizes the current situation and existing problems of performance appraisal of student affairs management personnel, and then constructs the system. From the view of $3 \mathrm{E}$ theory, it puts forward policy suggestions and management strategies for optimizing and improving the performance appraisal system of student affairs management personnel in Chinese universities, of which the purpose is to improve the performance efficiency of student affairs management personnel in Chinese universities.

\section{REFERENCES}

[1] Xiao Tianye. Research on "3E" theory of performance auditing [J].Business accounting, 2011, 6 (8) : 27-28

[2] [Germany] Marx Weber. Economics and society, Commercial Press. 1998

[3] Xing Junfang. Latest overseas performance auditing. China Audit Press.2001

[4] Deng Guosheng. Evaluation of Nonprofit Organizations. Social Sciences Literature Press. 2001. 